\title{
ESR DOSE RESPONSE OF THE AI CENTER MEASURED IN QUARTZ SAMPLES FROM THE YELLOW RIVER (CHINA): IMPLICATIONS FOR THE DATING OF UPPER PLEISTOCENE SEDIMENT
}

\author{
PIERRE VOINCHET ${ }^{1}$, GONGMING YIN ${ }^{2}$, CHRISTOPHE FALGUÈRES ${ }^{1}$, CHUNRU LIU $^{2}$, FEI HAN $^{2}$, \\ XUEFENG SUN ${ }^{3}$ and JEAN JACQUES BAHAIN ${ }^{1}$ \\ ${ }^{1}$ Département de Préhistoire du Muséum National d'Histoire Naturelle, UMR 7194 CNRS, 1 rue René Panhard, 75013 Paris, France \\ ${ }^{2}$ State Key Laboratory of Earthquake Dynamics, Institute of Geology, China Earthquake Administration, Beijing 100029, China \\ ${ }^{3}$ School of Geographical and Oceanographical Sciences, Nanjing University, No. 22 Hankou Road, Nanjing 210093, China
}

Received 29 January 2013

Accepted 29 August 2013

\begin{abstract}
The ESR dating method requires to describe the evolution of the ESR signal intensities vs. increasing gamma doses, then to extrapolate the equivalent dose of radiation received by the sample since its deposition using mathematical fitting. The function classically used to describe the growth curves of ESR aluminium signal in quartz was recently discussed and challenged for Lower Pleistocene sediments. In the present work, some alluvial sediments sampled in Upper Pleistocene fluvial terraces of the Yellow River system (China) permit us to test the application of another extrapolation function (linear + exponential) recently proposed for Lower Pleistocene sediments. The equivalent doses obtained here for the recent deposits of the Yellow River system and the corresponding ages are promising and indicate the potential of ESR to date quartz deposits from Upper Pleistocene times.
\end{abstract}

Keywords: ESR dating method, quartz, Upper Pleistocene, equivalent dose determination, exponential plus linear function.

\section{INTRODUCTION}

ESR is a classical dating method used in Quaternary Geology and Prehistory, particularly in the geochronological studies of alluvial terraces and associated prehistoric sites (Bahain et al., 2002; Despriée et al., 2011). One of the major interests of the method is to allow the dating of sediments deposited during the whole Lower and Middle Pleistocene. The ESR method is particularly suitable when seeking to date whole systems of alluvial terraces, set up following the climate changes and tectonic movements that have occurred throughout the Quaternary. The systematic dating of this type of stepped terraces system, using always

Corresponding author: P. Voinchet

e-mail: pvoinch@mnhn.fr the same method and analytical protocol, permits to easily compare the results between them and thus to reconstruct the evolution of the valley over a long period (Laurent et al., 1998; Voinchet et al., 2010, Tissoux et al., 2011).

Until recently, the dating by ESR of the lowest terrace levels of a fluvial system was considered not to be working properly. Indeed, the ages calculated for the lower terraces of several French fluvial systems were systematically overestimated and were rarely younger than $200 \mathrm{ka}$, in disagreement with the other available geochronological data (see for example in Laurent et al., 1998, Voinchet, 2002). For a long time, we explained that by the fact that these overestimated ages were due to the poor light sensitivity of aluminium (Al) center, used to determine the equivalent doses $\left(D_{E}\right)$ and therefore ages. 
An experimental study of artificial optical bleaching on sedimentary quartz has showed that the $\mathrm{Al}$ centre was maximally bleached after a 6 months natural light equivalent illumination (Voinchet et al., 2003). This value may seem too long to be observed in nature resulting in an incomplete bleaching, varying from one sample to the other. Then, we can suspect that a part of the measured signal could be related to this non-bleached dose (residual dose, $D_{r}$ ) that could explain the overestimation of the $D_{E}$ and ages. This unbleached dose is relatively low for old samples in comparison with their high accumulated dose $D_{A}\left(D_{E}=D_{A}+D_{r}, D_{A}>>D_{r}\right)$. However, for recent samples, the unbleached dose can be very important in comparison with the low accumulated dose $\left(\mathrm{D}_{\mathrm{E}}=\mathrm{D}_{\mathrm{A}}+\mathrm{D}_{\mathrm{r}} \approx \mathrm{D}_{\mathrm{r}}, \mathrm{D}_{\mathrm{r}}\right.$ $\left.>\mathrm{D}_{\mathrm{A}}\right)$.

On the other hand, a study performed on present-day fluvial deposits has permitted to check that the maximal bleaching was reached after a transportation of grain for a few kilometers (Voinchet et al., 2007). These grains are completely bleached and display only a residual signal associated with the presence of non-bleachable Al-centers (deep aluminium traps, DAT in Tissoux et al., 2012).

Moreover, studies regarding the behavior of the Alcenters ESR signal in quartz in response to thermal treatment, optical bleaching or gamma irradiation (Toyoda and Ikeya, 1994; Voinchet et al., 2003, Tissoux et al., 2012) have demonstrated the existence of different components with different growth or disappearance kinetics. It implies a new way to determine the $\mathrm{D}_{\mathrm{E}}$ before the age calculation. The single saturating exponential function initially used to describe the growth curves of $\mathrm{Al}$ center ESR intensities vs. increasing radiation doses (Yokoyama et al., 1985) failed in the case of recent deposits. The use of this equation was recently discussed, mainly for Early and Middle Pleistocene samples (Duval et al., 2011; Moreno, 2011; Cordier et al., 2012; Duval, 2012), and the use of more complex function was proposed but never applied to date Upper Pleistocene deposits.

The present study focuses on the dating of late Middle Pleistocene and Upper Pleistocene terraces, which form the last and lower levels of Quaternary fluvial systems, using the example of Yellow River system, China.

The fluvial system of the Yellow River in Zhongwei area (Ningxia Province, China) (Fig. 1) seemed particularly suited to such research concerning the dating of "recent" fluvial terraces. Indeed, it is composed of a set of 11 terraces stretches since the current alluvial flood plain up to $130 \mathrm{~m}$ of relative altitude (Xing et al., 2002). The lower terraces are clearly identified in the landscape and the entire region was little affected by human activity.

In order to date the Yellow River system by ESR, several sediments have been sampled in fluvial terraces attributed to Upper Pleistocene in November 2010, giving us the opportunity of such fitting studies. In this paper, the main results and conclusions of this study are presented.

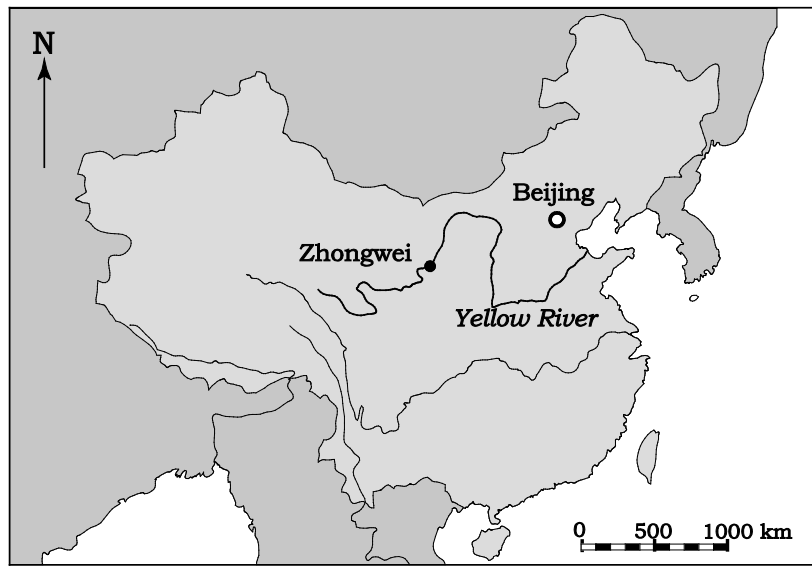

Fig. 1. Location of the studied area.

\section{MATERIAL AND METHOD}

\section{Sampling}

The Yellow river alluvial system, close to Zhongwei city, Ningxia Province, central China, is composed of a set of several stepped terraces, clearly observable in this semi-desert area. On the eleven levels described by Xing et al. (2002), only nine terraces were recognized during the present study (Fig. 2). It is therefore impossible to correlate easily the two described systems. Moreover, the studied area at present does not allow the access to the lowest alluvial formation described by Xing, due to the presence of a dam downstream. Additionally, our T3 seems to be a morphological terrace and only slope deposits were observed. This level was not sampled. Finally, we have not observed the highest terrace (T11) in the field.

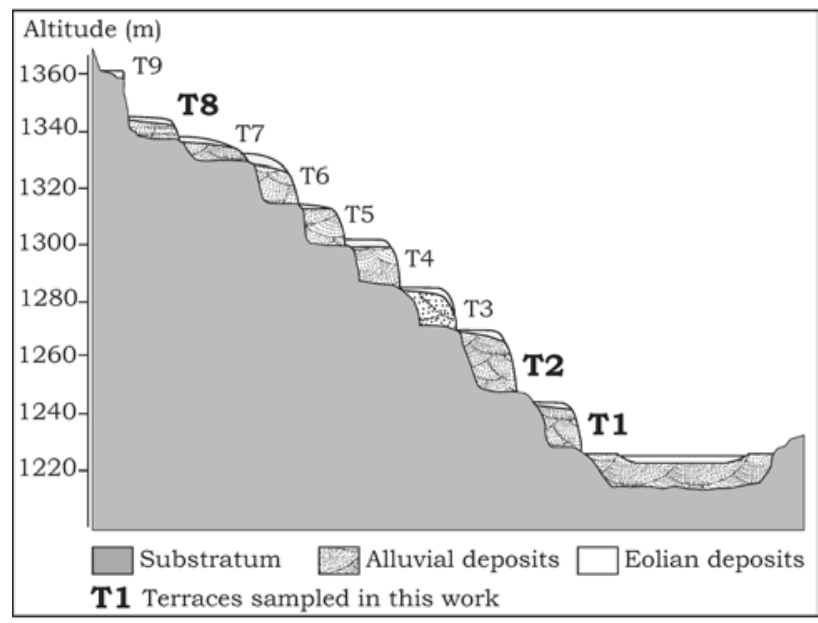

Fig. 2. Terraces system of Yellow River in the Zhongwei area. 
The two lower terraces (T1 and T2) of our alluvial system are located a few meters above the current level of the river and their installation is estimated to date from the late Pleistocene. T1 is located between $+1 /+10 \mathrm{~m}$ above the current river bed (relative altimetry). T2 is $+12 /+17$ m of relative height. T1 deposits consist of fine sands, sometimes silty. T2 sediments are fine sands.

Despite these supposed young ages, we have sampled these two alluvial formations at the same time then the other older fluvial remnants, in order to obtain a global view of the valley evolution. Three samples were taken in the terrace T1 (YR 05, YR 07 and YR 18), and four in the terrace T2 (YR 02, YR 03, YR 04 and YR 20).

A sample was also taken in one of the highest observed terraces of the system (T8, sample YR 16) in order to compare its dose response with the growth curves of the recent sediments.

\section{ESR dating method of bleached fluvial quartz using the $\mathrm{Al}$ center}

ESR is a paleodosimetric dating method. For this kind of method, samples are considered as dosimeters, which have recorded the total dose of ionising radiation received during the burial. This value can be estimated by the "additive dose method". The sample is separated into aliquots which are irradiated with increasing gamma doses. The additive method requires building a curve describing the evolution of the ESR signal as a function of increasing gamma doses, and then to extrapolate it to its intersection point with the $\mathrm{x}$-axis. Then, the total dose is equivalent to the value directly read on the $\mathrm{x}$-axis.

\section{Analytical protocol and age calculation}

Quartz is separated using a chemical and physical protocol already detailed in literature (e.g., Yokoyama et al., 1985; Voinchet et al., 2004). Irradiation of the aliquots is performed using a panoramic ${ }^{60} \mathrm{Co}$ source (Dolo et al., 1996) emitting $1.25 \mathrm{MeV} \gamma$-rays with a dose rate of $200 \mathrm{~Gy} / \mathrm{h}$. Nine aliquots were submitted to gamma doses ranging between 260 and 12,000 Gy.

ESR analyses were done on 100-200 $\mu \mathrm{m}$ quartz grains and we have chosen to use the $\mathrm{Al}$ paramagnetic center. This centre is optically bleached during the fluvial transport. The bleaching is not complete and the residual unbleachable signal must be determined and then subtracted from the ESR response prior to any age calculation. The determination of the proportion of nonbleachable deep centres (DAT) was performed using a solar simulator SOL2. The light intensity then received by each aliquot ranges between 3.2 and $3.4 \times 10^{5}$ lux and samples were illuminated for $1600 \mathrm{~h}$. The bleached aliquots ESR intensity was subtracted from the intensities of other aliquots (including natural) before the construction of the growth curve.

ESR measurements were performed at $107 \mathrm{~K}$ with a Bruker EMX spectrometer using the experimental condi- tions proposed by Voinchet et al. (2004). The signal intensity is measured between the top of the first peak at $\mathrm{g}=2.018$ and the bottom of the $16^{\text {th }}$ peak at $\mathrm{g}=2.002$ of the Al hyperfine structure (Toyoda and Falguères, 2003). Each aliquot was measured three times after a rotation of an angle of $120^{\circ}$ from its initial position in the cavity. This protocol was repeated three times representing 9 measurements for each aliquot.

The regression curves were obtained using the Microcal OriginPro 8 software. Data were weighted by the inverse of the squared intensity, $1 / \mathrm{I}^{2}$ (Yokoyama et al. 1985).

The dose rate was calculated from the radionuclide activities obtained by gamma-ray spectrometry measurements in situ (Inspector 1000, Canberra) using the threshold method of Mercier and Falguères (2007) and in our laboratory (Ortec low background germanium spectrometer). Age calculations were assessed using the doserate conversions factors from Adamiec and Aitken (1998), a k-value of 0.15 \pm 0.1 (Yokoyama et al., 1985; Laurent et al., 1998), $\alpha$ and $\beta$ attenuation factors from Brennan (2003) and Brennan et al. (1991), water attenuation formulae from Grün (1994). The water content is measured by the difference in mass between the natural sample and the same sample dried for a week.

The cosmic dose rate contribution was calculated from the equations of Prescott and Hutton (1994). The internal dose rate was considered as negligible because of the low contents of radionuclides usually found in quartz grains (Murray and Roberts, 1997; Vandenberghe et al., 2008).

\section{Dose response of Al-center in quartz}

Since the first optically bleached quartz grains dating by ESR (Yokoyama et al., 1985), a single saturating exponential function (SSE) (Ikeya, 1981; Apers et al., 1981) has been systematically used to fit the Al center dose response curve:

$$
I(D)=I_{s a t}\left(1-e^{-\mu\left(D+D_{E}\right)}\right)
$$

where $I$ is the intensity of the ESR signal of a sample irradiated at the dose $D, I_{\text {sat }}$ the saturation intensity, $\mu$ the coefficient of sensitivity of the sample and $D_{\mathrm{E}}$ the equivalent dose.

In this mathematical approach, while the number of trapped electrons increases, the possibility of a new electron trapping decreases and the curve approach asymptotically to a maximum intensity value $\left(I_{\text {sat }}\right)$ that corresponds to the saturation of the system.

The analysis of quartz samples from terraces of very different ages shows however that the SSE formula, does not fully describe the evolution of the ESR intensity during gamma irradiation of quartz grains (Duval, 2009).

For samples of ancient terraces (Fig. 3), this equation does not take into account the slope failures frequently 
observed in the growth curve, which increases the uncertainty in the determination of the $\mathrm{D}_{\mathrm{E}}$.

For recent samples, the curve constructed from the equation through a few points and does not fit at high doses, causing systematic overestimation of the $\mathrm{D}_{\mathrm{E}}$ and a significant error (Fig. 4), as it had already been noted for Middle Pleistocene samples by Duval (2012). This phenomenon has been described for other dated materials such as tooth enamel (Duval et al., 2009), and the use of another function corresponding to the sum of a SSE function and a linear term $(\mathrm{E}+\mathrm{L})$ was proposed for teeth then for quartz (Duval et al., 2011; Moreno, 2011; Cordier et al., 2012 and Duval, 2012), considering that the global ESR signal is the result of the presence of two components in the $\mathrm{Al}$ signal:

$$
I(D)=I_{s a t}\left(1-e^{-\mu\left(D+D_{E}\right)}\right)+B\left(D+D_{E}\right)
$$

where $I$ is the intensity of the ESR signal of a sample irradiated at the dose $D, I_{\text {sat }}$ the saturation intensity, $\mu$ the coefficient of sensitivity of the sample and $D_{\mathrm{E}}$ the equivalent dose. The linear term represents the filling of traps existing prior to artificial irradiation. It depends thus on this radiation dose and the equivalent dose and saturates far beyond the maximal added artificial dose. B represents the radiation sensitivity of this term.

Ages calculated using this new equation have been recently published for quartz of Lower Pleistocene and Middle Pleistocene ages (Duval et al. 2011; Moreno, 2011; Cordier et al., 2012; Duval, 2012). The use of this equation has brought better accuracy for these ages and their use to date more recent sediments seems possible. In order to check this point, several sediment samples from Yellow River system were analyzed in the present work.

\section{RESULTS AND DISCUSSIONS}

$\mathrm{U}, \mathrm{Th}, \mathrm{K}$ concentrations, water content, estimated cosmic dose and bleaching rate are displayed in Table 1.

Equivalent doses (and ages) were determined using both fitting functions. Results are displayed in Table 2.

As mentioned previously for others samples, we observe very different kinetics of intensity growth for the ESR Al signal curve between recent samples (whose age is between 10 and $200 \mathrm{ka}$ ) and ancient samples for YR sediments.

- For very recent samples, two distinct domains of growth are clearly visible on the curves, with an initial extremely rapid growth for the first doses and later a much slower one for high doses. In such conditions, using the classical SSE function to determine the equivalent dose systematically leads to an overestimation of the equivalent dose and, consequently, the age (Fig. 4). This scheme in two domains, with a very rapid growth and then linearity, shows before any calculation that the sediment would provide relatively

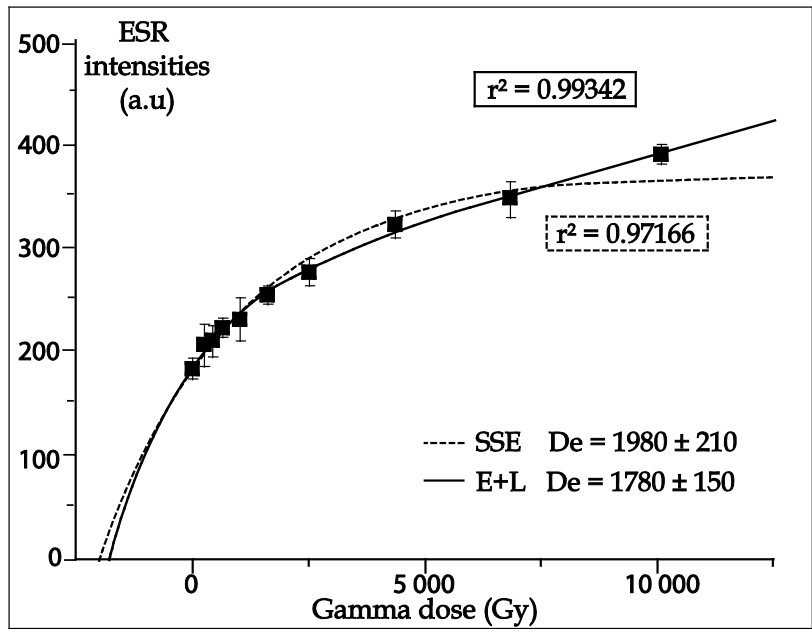

Fig. 3. Growth curve of $Y R 16$ sample, comparison of the two different fitting equations. Errors in every points correspond to the nine measures standard deviation.

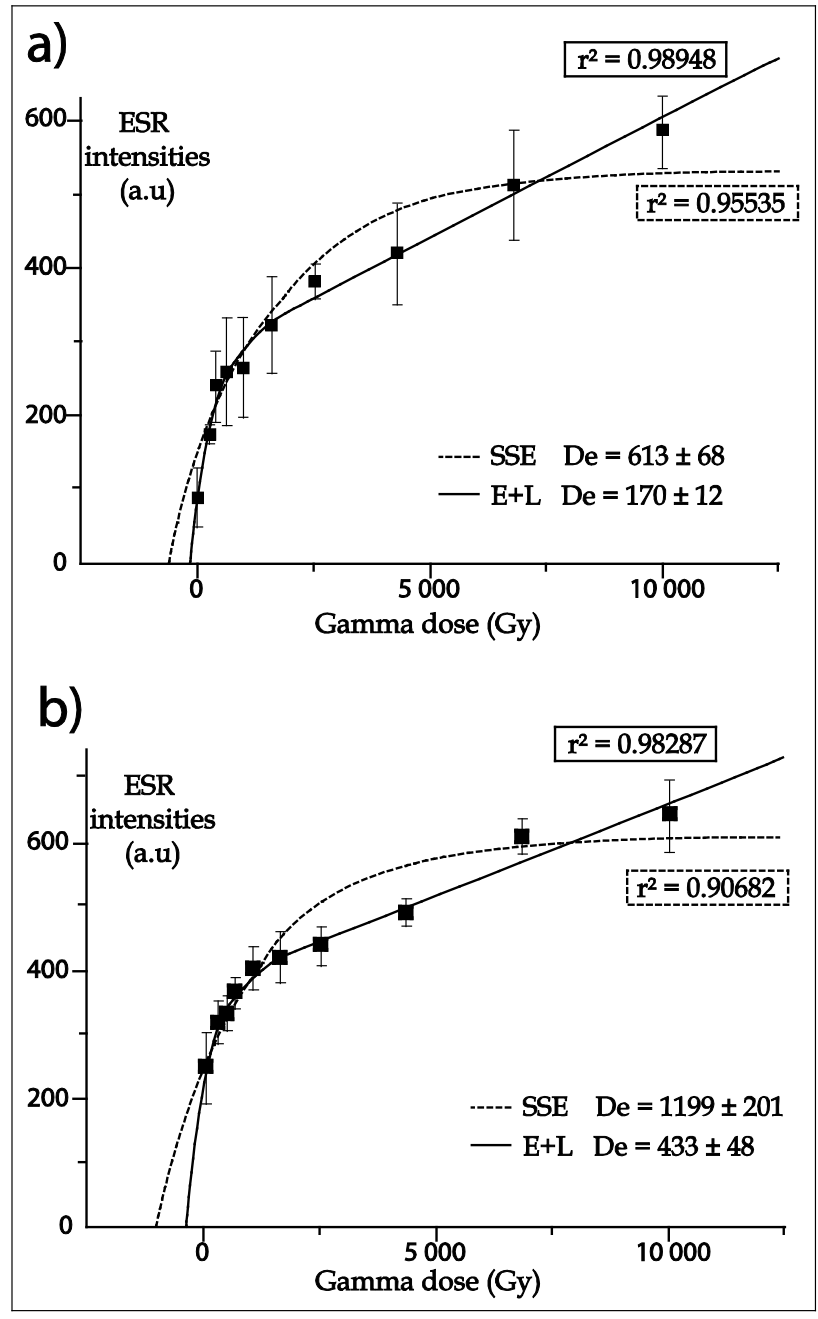

Fig. 4. a) Growth curve of YR 07 sample, comparison of the two different fitting equations; b) Growth curve of YR 03 sample, comparison of the two different fitting equations. Errors in every points correspond to the nine measures standard deviation. 
P. Voinchet et al.

Table 1. Radiometric data obtained for the samples taken in the alluvial terraces of Yellow river system. The following analytical data are showed: $U$, $R a, R n$, Th and $K$ activities, maximal bleaching percentage (BI.), sediment water content (W) and estimated cosmic dose.

\begin{tabular}{|c|c|c|c|c|c|c|c|c|c|}
\hline Terrace & Sample & $\underset{(\mathrm{dpm} / \mathrm{g})}{U}$ & $\begin{array}{c}\mathrm{Ra} \\
(\mathrm{dpm} / \mathrm{g})\end{array}$ & $\begin{array}{c}\mathrm{Rn} \\
(\mathrm{dpm} / \mathrm{g})\end{array}$ & $\begin{array}{c}\text { Th } \\
\text { (dpm/g) }\end{array}$ & $\begin{array}{c}K \\
(\%)\end{array}$ & $\begin{array}{c}\mathrm{Bl} \\
(\%)\end{array}$ & $\begin{array}{l}W \\
(\%)\end{array}$ & $\begin{array}{c}\text { Cosmic } \\
\text { Dose } \\
\text { ( } \mu \text { Gylan) }\end{array}$ \\
\hline \multirow{3}{*}{$\mathrm{T} 1$} & YR 05 & $1.333 \pm 0.07$ & $1.291 \pm 0.148$ & $1.162 \pm 0.022$ & $1.547 \pm 0.035$ & $1.744 \pm 0.019$ & 49 & 18 & $167 \pm 8$ \\
\hline & YR 07 & $1.771 \pm 0.07$ & $1.732 \pm 0.127$ & $1.547 \pm 0.021$ & $1.877 \pm 0.032$ & $1.872 \pm 0.056$ & 41 & 17 & $181 \pm 9$ \\
\hline & YR 18 & $2.036 \pm 0.07$ & $1.655 \pm 0.127$ & $1.766 \pm 0.022$ & $2.239 \pm 0.032$ & $2.045 \pm 0.056$ & 39 & 17 & $197 \pm 10$ \\
\hline \multirow{4}{*}{ T2 } & YR 02 & $1.675 \pm 0.06$ & $2.002 \pm 0.120$ & $1.805 \pm 0.021$ & $1.792 \pm 0.029$ & $1.517 \pm 0.014$ & 47 & 18 & $200 \pm 10$ \\
\hline & YR 03 & $2.059 \pm 0.06$ & $1.759 \pm 0.115$ & $1.935 \pm 0.020$ & $1.960 \pm 0.028$ & $1.438 \pm 0.013$ & 46 & 20 & $105 \pm 5$ \\
\hline & YR 04 & $2.565 \pm 0.08$ & $2.289 \pm 0.160$ & $2.071 \pm 0.028$ & $1.974 \pm 0.039$ & $1.455 \pm 0.018$ & 53 & 20 & $181 \pm 9$ \\
\hline & YR 20 & $1.942 \pm 0.05$ & $1.657 \pm 0.110$ & $1.648 \pm 0.018$ & $2.119 \pm 0.028$ & $1.692 \pm 0.013$ & 53 & 12 & $62 \pm 3$ \\
\hline T8 & YR 16 & $1.771 \pm 0.04$ & $1.648 \pm 0.087$ & $1.531 \pm 0.014$ & $1.802 \pm 0.021$ & $1.315 \pm 0.009$ & 53 & 17 & $167 \pm 8$ \\
\hline
\end{tabular}

Table 2. ESR data and ages obtained for the samples taken in the alluvial terraces of Yellow river system. The following analytical data are showed: equivalent dose obtained using SSE fitting ( $\left.D_{E} S S E\right)$ and using $E+L$ fitting $\left(D_{E} E+L\right)$, dose rate and obtained age with the two fitting procedure.

\begin{tabular}{ccccccc}
\hline Terrace & Sample & $\begin{array}{c}\text { Dose rate } \\
(\boldsymbol{\mu G y / a n )}\end{array}$ & $\begin{array}{c}\text { De SSE } \\
(\text { Gy) }\end{array}$ & $\begin{array}{c}\text { Ages } \\
\text { SSE (ka) }\end{array}$ & $\begin{array}{c}\text { De E+L } \\
(\text { Gy) }\end{array}$ & $\begin{array}{c}\text { Ages } \\
\text { E+L (ka) }\end{array}$ \\
\hline \multirow{3}{*}{ T1 } & YR 05 & $2805 \pm 279$ & $993 \pm 53$ & $354 \pm 40$ & $225 \pm 14$ & $80 \pm 9$ \\
& YR 07 & $2998 \pm 280$ & $613 \pm 68$ & $203 \pm 23$ & $170 \pm 12$ & $57 \pm 6$ \\
& YR 18 & $3495 \pm 302$ & $736 \pm 71$ & $210 \pm 26$ & $185 \pm 15$ & $53 \pm 5$ \\
\hline \multirow{3}{*}{ T2 } & YR 02 & $2568 \pm 241$ & $1188 \pm 152$ & $463 \pm 50$ & $498 \pm 60$ & $194 \pm 29$ \\
& YR 03 & $2608 \pm 260$ & $1199 \pm 201$ & $460 \pm 60$ & $433 \pm 47$ & $166 \pm 25$ \\
& YR 04 & $2957 \pm 280$ & $2761 \pm 141$ & $933 \pm 103$ & $2395 \pm 130$ & $810 \pm 98$ \\
\hline T8 & YR 20 & $2816 \pm 270$ & $1272 \pm 260$ & $451 \pm 52$ & $506 \pm 80$ & $180 \pm 27$ \\
\hline
\end{tabular}

recent age (late Middle Pleistocene or Upper Pleistocene).

- For old sample, the curve does not clearly show different growth domains, and applying the SSE equation or $\mathrm{E}+\mathrm{L}$ equation is statistically indistinguishable (Fig. 3). However, the use of $\mathrm{E}+\mathrm{L}$ gives a smaller error range and generally a smaller $\mathrm{D}_{\mathrm{E}}$ value (3-5\%).

We can note that the results obtained using the two methods for the fitting show some similarities, essentially in terms of homogeneity within the different terraces. Two age groups are then obtained for the T1. Ages provided by YR 07 and YR 18 samples are very close and YR05 seems older. This age seems to be overestimated, especially for the terrace situated a few meters above the current level of the river. The three samples have the same relative altitude and there is no evidence of fault movement or slipping to explain simply $\mathrm{D}_{\mathrm{E}} 5$ to 6 times greater than those observed for the other remnants to the terrace.

This age could indicate that the sediment had not been sufficiently bleached prior to its deposition or a contamination of the sediment with unbleached grains. Indeed, when a quartz grain is deposited without being completely bleached, the residual dose will add up to the accumulated dose during the burial and thus increase the value of the calculated age. In this case, for recent sediment incompletely bleached prior to deposition, the accumulated dose (since the deposition) is small in comparison to the residual dose. The induced error or overestimation in $D_{E}$ determination is then very significant and would explain overestimation of the age obtained here. The risks of insufficient bleaching seem important for silty or siltysandy deposits. The transportation of grains in turbid water could in fact prevent the penetration of UV in deep water and limit their action on sands.

For the T2 terrace, two groups are also identified. YR 02, YR 03 and YR 20 show consistent age (around 180 $\mathrm{ka}$ ), whereas YR 04 was significantly older, and its age was probably overestimated. The growth curve of this sample is very similar to those obtained for the samples from the highest terraces (no rapid growth for the lowest doses and so high $\mathrm{D}_{\mathrm{E}}$ ). Sedimentological analysis revealed in the corresponding sediment the presence of aeolian quartz grains (quartz grains morphoscopy). Unlike the other samples where the selected grain size quartz has single origin, the grains of this sample probably correspond to two different deposition ways. The two subsequent populations of grains do not have the same story and not the same characteristic. The presence of these grains in the sample makes impossible the building of a significant growth curve. It can explain the overestimated age of the sample YR 04.

Nevertheless, there are important differences between the two sets of results obtained using the two ways of $D_{E}$ calculation. These results result in very different conclusions for the reconstruction of the history of the alluvial 
system. Hence in the present case, if we consider the SSE ages, the Yellow River stepped system history will be mainly of Middle Pleistocene age and strongly affected by the tectonic uplift, without evolution during the last $200 \mathrm{ka}$, in disagreement with other stratigraphical and palaeontological evidences (see for exemple Porter et al., 1992; Yin et al., 2013). If we consider the second case ( $\mathrm{E}+\mathrm{L}$ ages), the incision has continued during the whole Middle Pleistocene and the Upper Pleistocene until very recently. This evolution indicates a continuous regional uplift since the early Middle Pleistocene and place the onset of the stepped system close to the Lower-Middle Pleistocene limit, ca. 780 ka ago.

Comparisons between our results and ages obtained through other methods (ESR measurement using Ti center, OSL) that are being implemented will help to better define the context of the implementation of the Yellow River system.

\section{CONCLUSION}

The geochronological results obtained for the Quaternary alluvial deposits of the Yellow river illustrate clearly that during irradiation of samples of quartz, there are several answers of the $\mathrm{Al}$ center depending on the added doses. This phenomenon is much more noticeable for samples with small $D_{E}$, and hence for very recent samples (late Middle Pleistocene and Upper Pleistocene).

The use of several terms regression functions allows us to take this phenomenon into account, and provides dates for deposits of less than $100 \mathrm{ka}$. Ages obtained for lowest levels indicate the potential of ESR in quartz to date samples from the Upper Pleistocene. These results open new perspectives for samples until now considered non-datable.

\section{ACKNOWLEDGMENTS}

We thank the French Chinese PHC "Cai Yuanpei" program (EGIDE-MAEE) and the China Earthquake Administration for allowing us to make studies on alluvial formations in China; We thank also the two referees for their valuable comments.

\section{REFERENCES}

Adamiec G and Aitken M, 1998. Dose-rate conversion factor: update. Ancient TL 16: 37-50.

Apers D, Debuyst R, De Cannière P, Dejehet F and Lombard E, 1981. A criticism of the dating by electron paramagnetic resonance (ESR) of the stalagmitic floors of the Caune de l'Arago at Tautavel. In : Absolute dating and Isotope Analysis in Prehistory - Methods and limits (eds H. de Lumley and J. Labeyrie),pp 533-550, CNRS, Paris.

Bahain JJ, Bahain J-J, Laurent M, Falguères C, Voinchet P, Farkh S and Tissoux H., 2002. Datation par résonance paramagnétique électronique (RPE) des formations fluviatiles pléistocènes et des gisements archéologiques ou paléontologiques associés. Quaternaire 13(2): 91-103
Brennan B, Lyons R and Phillips S, 1991. Attenuation of alpha particle track dose for spherical grains. Nuclear Tracks Radiational Measurements 18(1-2): 249-253, DOI 10.1016/1359-0189(91)90119-3.

Brennan BJ, 2003. Beta doses to spherical grains. Radiation Measurements 37(4-5): 299-303, DOI 10.1016/S1350-4487(03)00011-8.

Cordier S, Harmand D, Lauer T, Voinchet P, Bahain JJ and Frechen M, 2012. Geochronological reconstruction of the Pleistocene evolution of the Sarre valley (France and Germany) using OSL and ESR dating techniques Geomorphology 165-166: 91-106, DOI 10.1016/j.geomorph.2011.12.038.

Despriée J, Voinchet P, Tissoux H, Bahain J-J, Falguères C, Courcimault G, Dépont J, Moncel M-H, Robin S, Arzarello M, Sala R, Marquer L, Messager E, Puaud S and Abdessadok S, 2011. Lower and Middle Pleistocene human settlements recorded in fluvial deposits of the middle Loire River Basin, Centre Region, France. Quaternary Science Reviews 30(11-12): 1474-1485, DOI 10.1016/j.quascirev.2011.02.011.

Dolo JM, Lecerf N, Mihajlovic V, Falguères C and Bahain JJ, 1996. Contribution of ESR dosimetry for irradiation of geological and archaeological samples with a 60-Co panoramic source, Applied Radiation and Isotopes 47(11-12): 1419-1421, DOI 10.1016/S0969-8043(96)00205-9.

Duval M, 2009. Evaluation du potentiel de la méthode de datation par Résonance de Spin Electronique (ESR) appliquée aux gisements du Pléistocène inférieur : étude des gisements d'Orce (bassin de Guadix-Baza, Espagne) et contribution à la connaissance des premiers peuplements de l'Europe. Thèse de doctorat du Muséum National d'Histoire Naturelle, Paris. (Evaluation of the potential and limits of the Electron Spin Resonance (ESR) dating method applied to the Lower Pleistocene sites of Orce (Guadix-Baza basin, Spain) and a contribution to the understanding of the first human settlements of Europe. PhD thesis, Muséum National d'Histoire Naturelle, Paris). $522 p$

Duval M, Grün R, Falguères C, Bahain JJ, Dolo JM, 2009. ESR dating of Lower Pleistocene fossil teeth: Limits of the single saturating exponential (SSE) function for the equivalent dose determination. Radiation Measurements 44(5-6): 477-482, DOI 10.1016/j.radmeas.2009.03.017.

Duval M, Moreno D, Shao Q, Voinchet $\mathrm{P}$ and Falguères C, 2011. Datación por ESR del yacimiento arqueológico del Pleistoceno inferior de Vallparadís (Terrassa, Cataluña, España). (ESR dating of the Early Pleistocene archaeological site at Vallparadís (Terrassa, Cataluña, Spain). Trabajos de Prehistoria 68(1) 7-24 (in Spanish).

Duval M, 2012. Dose response curve of the ESR signal of the Aluminum center in quartz grains extracted from sediment. Ancient $T L$ 30(2): 41-49.

Grün R, 1994. A cautionary note: use of the "water content" and "depth for cosmic ray dose rate" in AGE and DATA. Ancient TL 12: 5051.

Ikeya M, 1981. Dating methods and limitation by electron spin resonance (ESR). Absolute dating and isotope analysis in prehistory methods and limits proceeding, Lumley $\mathrm{H}$ (de) et Labeyrie J eds, $\mathrm{p}$ 437-455

Laurent M, Falguères C, Bahain JJ, Rousseau L and Van Vliet-Lanoë B, 1998. ESR dating of quartz extracted from Quaternary and Neogene sediments: method, potential and actual limits. Quaternary Science Reviews 17(11): 1057-1062, DOI 10.1016/S02773791(97)00101-7.

Mercier N and Falguères C, 2007. Field gamma dose-rate measurement with a $\mathrm{NaI}(\mathrm{Tl})$ detector: re-evaluation of the "threshold" technique. Ancient TL 25(1): 1-4.

Moreno D, 2011. Datation par ESR de quartz optiquement blanchis (ESR-OB) de la région de Atapuerca (Burgos, Espagne). Application au site préhistorique de Gran Dolina (contexte karstique) et aux systèmes fluviatiles quaternaires de l'Arlanzón et l'Arlanza. Thèse de doctorat du Muséum National d'Histoire Naturelle, Paris. et Universitat Rovira $i$ Virgili, Tarragone. (ESR dating (ESR$\mathrm{OB}$ ) of the Atapuerca area (Burgos, Spain). Application to the dating of Gran Dolina prehistorical site (karstic context) and quaternary fluvial systems of Arlanzon and Arlanza Rivers.PhD thesis, Muséum National d'Histoire Naturelle, Paris), 268 p. 
Murray AS and Roberts RG, 1997. Determining the burial time of single grains of quartz using optically stimulated luminescence. Earth and Planetary Science Letters 152(1-4): 163-180, DOI 10.1016/S0012-821X(97)00150-7.

Porter S, An Z and Zheng H, 1992. Cyclic Quaternary Alluviation and Terracing in a Nonglaciated Drainage Basin on the North Flank of the Qinling Shan, Central China. Quaternary Research 38(2): 157169, DOI 10.1016/0033-5894(92)90053-L.

Prescott JR and Hutton JT, 1994. Cosmic ray contributions to dose rates for Luminescence and ESR Dating: Large depths and long-term time. Radiation Measurements 23(2-3): 497-500, DOI 10.1016/1350-4487(94)90086-8.

Tissoux H, Despriée J, Voinchet P, Bahain JJ, Falguères C and Duvialard J, 2011. Intérêt de la datation par ESE d'un transect complet pour la compréhension d'un système fluviatile: Exemple de la vallée du Loir. (ESR dating of a complete cross-section interest for the understanding of a fluvial system: the Loir Valley example). Quaternaire 22(4): 345-356.

Tissoux H, Voinchet P, Lacquement F, Prognon F, Moreno D, Falguères $\mathrm{C}$, Bahain $\mathrm{JJ}$ and Toyoda $\mathrm{S}, 2012$. Investigation on nonoptically bleachable components of ESR aluminium signal in quartz. Radiation Measurements 47(9): 894-899, DOI 10.1016/j.radmeas.2012.03.012.

Toyoda S and Ikeya M, 1994. ESR dating of quartz with stable components of impurity centers. Quaternary Science Reviews 13(5-7): 625-628, DOI 10.1016/0277-3791(94)90089-2.

Toyoda S and Falguères $\mathrm{C}, 2003$. The method to represent the ESR intensity of the aluminium hole center in quartz for the purpose ofdating. Advances in ESR applications 20: 7-10.

Vandenberghe D, De Corte F, Buylaert J-P, Kučera J and Van Den Haute P, 2008. On the internal radioactivity in quartz. Radiation Measurements 43(2-6): 771-775, ROI 10.1016/j.radmeas.2008.01.016.

Voinchet P, 2002. Datation par résonance paramagnétique électronique (RPE) de quartz blanchis extraits de sédiments fluviatiles pléistocènes : contribution méthodologique et application aux systèmes de la Creuse, du Loir et de l'Yonne. Thèse de doctorat du Muséum
National d'Histoire Naturelle. (Electronic Spin Resonance (ESR) dating of optically bleached quartz extracted from Pleistocene fluvial sediments: methodological contribution and dating application to the systems of the Creuse, Loir and Yonne Rivers. PhD thesis, Muséum National d'Histoire Naturelle, Paris). Paris. 268 p.

Voinchet $\mathrm{P}$, Falguères $\mathrm{C}$, Laurent M, Toyoda $\mathrm{S}$, Bahain JJ and Dolo JM, 2003. Artificial optical bleaching of the Aluminium center in quartz implications to ESR dating of sediments. Quaternary Science Reviews, 22(10-13): 1335-1338, DOI 10.1016/S02773791(03)00062-3.

Voinchet $\mathrm{P}$, Bahain JJ, Falguères $\mathrm{C}$, Laurent $\mathrm{M}$, Dolo JM, Despriée J and Gageonnet R, 2004. ESR dating of quartz extracted from Quaternary sediments: Application to fluvial terraces system of Northern France. Quaternaire 15(1-2): 135-141.

Voinchet P, Despriée J, Tissoux H, Falguères C, Bahain J.-J, Gageonnet R, Dépont J and Dolo J-M, 2010. ESR chronology of alluvial deposits and first human settlements of the Middle Loire Basin (Region Centre, France). Quaternary Geochronology 5(2-3): 381-384, DOI 10.1016/j.quageo.2009.03.005.

Voinchet $\mathrm{P}$, Falguères $\mathrm{C}$, Tissoux H, Bahain JJ, Despriée J and Pirouelle F, 2007. ESR dating of fluvial quartz: estimate of the minimal distance transport required for getting a maximum optical bleaching. Quaternary Geochronology 2(1-4): 363-366, DOI 10.1016/j.quageo.2006.04.010.

Xing C, Yin G, Ding G, Lu Y, Shen X, Tina Q, Chai Z and Wei K, 2002. Thickness of calcium carbonates coats on stones of the Heishanxia terraces of the Yellow river and dating of coarse clastic sedimentary geomorphic surfaces. Chinese Science Bulletin 47(19): 1594-1600, DOI 10.1007/BF03184104.

Yin G, Wang X and Han F, 2013. The age of the Shapotou desert based on OSL ages of aeolian sediments in the Yellow River terraces, Ningxia Hui autonomous region, northern China. Quaternary Sciences 33(2): 269-275.

Yokoyama Y, Falguères C, Quaegebeur JP, 1985. ESR dating of quartz from Quaternary sediments: first attempt. Nuclear Tracks and Radiation Measurements 10(4-6): 921-928, DOI 10.1016/0735245X(85)90109-7. 